\title{
Pharmaceutic guidance to hypertensive patients at USP University Hospital: effect on adherence to treatment
}

\author{
Ana Luiza Pereira Moreira Mori ${ }^{1, *}$, Joel Claudio Heimann², Egídio Lima Dórea ${ }^{3}$, Márcia Martins \\ Silveira Bernik ${ }^{4}$, Sílvia Storpirtis ${ }^{1,5}$
}

\begin{abstract}
${ }^{1}$ Pharmacy Department, Faculty of Pharmaceutical Sciences, University of São Paulo, ${ }^{2}$ Department of Clinical Medicine, Faculty of Medicine, University of São Paulo, ${ }^{3}$ Hypertension Outpatient Clinic, University Hospital, University of São Paulo, ${ }^{4}$ Division of Clinical Medicine, University Hospital, University of São Paulo, ${ }^{5}$ Division of Pharmacy and Clinical Lab, University Hospital, University of São Paulo.
\end{abstract}

\begin{abstract}
This study was carried out in the outpatient unit of the Teaching Hospital of the University of São Paulo (USP), and studied the impact of an educational program aimed at improving hypertensive patients' compliance to treatment. Seventy five (75) hypertensive patients of both sexes took part in the study which had no age or race discrimination. Participants presented no other concomitant pathology, except obesity, diabetes and dyslipidemia. Forty one patients were allocated to an experimental group (EG). Experimental patients attended lectures on the use of medication and artery hypertension (AH) and received personal pharmaceutical guidance for nine months. The control group (CG) comprised 34 patients who did not attend lectures or receive pharmaceutical advice in this period. The results were assessed by means of serum levels of cholesterol and fractions of tryacylglicerol (TG), urine sodium and potassium, arterial pressure (AP), body mass index (BMI), waist-hip ratio (WHR), and also based on responses to a questionnaire focusing on $\mathrm{AH}$ and treatment. Patients who received the guidance showed a greater decrease in AP, TG and WHR, besides an increase of potassium excretion through urine. The experimental group also scored higher on the questionnaires compared to the CG. It was concluded that the educational process, applied under the conditions of the present study, improves clients' clinical response to antihypertensive treatment and should be included in therapeutic strategies of health care services dealing with hypertensive patients.
\end{abstract}

Uniterms: Arterial hypertension/adhesion to treatment. Health Education. Pharmaceutical Care.

Este trabalho, realizado no ambulatório do Hospital Universitário da USP, estudou a repercussão de um programa educacional visando melhorar a adesão do paciente hipertenso ao tratamento. Participaram do trabalho 75 pacientes de ambos os sexos, sem discriminação de idade ou raça, sem outras patologias concomitantes, exceto obesidade, diabetes e dislipidemia. Quarenta e um pacientes assistiram palestras sobre uso de medicamentos e hipertensão arterial (HA), receberam orientação farmacêutica individualizada durante nove meses e foram denominados grupo experimental (GE); o grupo controle (GC), composto por 34 pacientes não assistiu palestras nem recebeu orientação farmacêutica, neste período. Os resultados foram avaliados por meio de níveis séricos de colesterol e frações, triacil-gliceróis (TG), sódio e potássio urinários, pressão arterial (PA), índice de massa corpórea (IMC), relação cintura/quadril (RCQ), além de respostas a questionário enfocando HA e tratamento. Verificou-se que os pacientes orientados apresentaram maior decréscimo da PA, TG e da RCQ, além de aumento da excreção urinária de potássio e do percentual de acertos em questionários, em relação ao GC. Concluiu-se que o processo educativo, utilizado nas condições deste estudo, melhora a resposta clínica do paciente ao tratamento anti-hipertensivo e deve fazer parte das estratégias terapêuticas de serviços de atendimento a pacientes hipertensos.

Unitermos: Hipertensão arterial/adesão ao tratamento. Educação em Saúde. Atenção Farmacêutica.

\footnotetext{
*Correspondence: A. L. P. M. Mori. Pharmacy Department, Faculty of Pharmaceutical Sciences, University of São Paulo - 05508-000 - Av. Prof. Lineu Prestes, 2565 - University Hospital - USP - DFLC- $3^{\circ}$ andar. E-mail: alpmm@yahoo.com
} 


\section{INTRODUCTION}

Arterial hypertension is a condition characterized by a chronic increase in arterial pressure, which internationally is considered higher than the normal limit of $120 \mathrm{mmHg}$ for systolic arterial pressure, and $80 \mathrm{mmHg}$ for diastolic pressure. According to the Joint National Committee (2004), individuals with systolic arterial pressure in the range 120-139 $\mathrm{mmHg}$ and/or diastolic arterial pressure of around $80-89 \mathrm{mmHg}$ are classified as pre-hypertensive while those with levels above 140/90 $\mathrm{mmHg}$ are classified as hypertensive. Several factors predispose individuals to $\mathrm{AH}$, the main ones being hereditary cause, race, sex, age, excessive use of salt, obesity and sedentarism. The prevalence of $\mathrm{AH}$ is estimated at $20 \%$ of the world adult population, plus a significant number of children and adolescents who may harbor the disease. $\mathrm{AH}$ is one of the main risk factors for cardiovascular diseases, causing $40 \%$ of deaths by cerebrovascular accident and $25 \%$ by coronary disease, according to Quinta (2006). The disease increases with age and is found in about $50 \%$ of individuals aged over 55 years (Hermansen, 2000). In a study by Johnson (1999), over 500,000 cerebrovascular accidents and one million myocardial infarctions were found to be registered each year by the US National Center of Health Statistics as a result of this pathology.

This condition is also responsible for some $40 \%$ of cases of early retirement and a significant number of absences from work, causing not only serious health problems in patients but also a high social cost (Terceiro, 1998).

There is a sufficient arsenal of therapeutic options to allow the control of arterial pressure in all hypertensive individuals. However, the percentage of success of antihypertensive therapeutics is far from ideal. One of the causes of this failure in the treatment of hypertensive individual is the lack of compliance with the recommendations given to patients, according to Basile, NicholsEnglish, Waeber (2000). Treatment noncompliance by patients with chronic diseases is a major problem in public health of epidemic proportions, and is called the invisible epidemic. Patient compliance to therapeutic treatment can also be defined, according to Burnier (2000), as the faithful compliance with medication or non-medication treatment prescribed by doctors or other health professionals. Nonmedication treatment includes dietary/nutritional recommendations, physical exercises and obesity correction, and involves alterations to one's lifestyle, according to Korhonen (1999) and Weier (2000).

Compliance to altering one's lifestyle, according to Margetts (1999), may cause a substantial impact in the re- duction of morbidity and mortality of the population with this chronic condition. Neutel (1999) carried out studies on the prevalence of hypertension in the adult population in the US, and found that only $27 \%$ of patients follow the hypertensive treatment correctly, and managed to keep their arterial pressure under control. It is estimated that about half of the 2 billion medication prescriptions made out for hypertension treatment worldwide every year are incorrectly followed. Brouker (2000) reported that one sixth of all hospital admissions and 2.5 million cases seen in emergency rooms every year involve hypertensive patients who are not compliant to the treatment. Also, according to Heisler (2008), the results of low compliance to treatment may be evidenced by the increase in prescription of doses that are unnecessary for the treatment, or by changes in medication, even when these are unable to keep the arterial pressure within normal levels, and cause an increase in the number of avoidable hospital admissions of hypertensive patient cases which consequently raises the costs of health care for both the patient and government agencies.

Pharmaceutical Care has been defined in terms of the World Health Organization (2002), as "a model of pharmaceutical practice developed in the Pharmaceutical Care context. It comprises attitudes, ethical values, behaviors, commitments and co-responsibilities in the prevention of diseases, promotion and recovery of health, in a way that is integrated with health teams. It is the direct interaction between pharmacists and users, with a view to achieving rational pharmacotherapy and obtaining defined and measurable results which translate to improvement in life quality".

According to Ivama, Jaramillo (2008) and Bonal (2008), Pharmaceutical Care, one characteristic of which is the interaction between the pharmacist and the members of a multidisciplinary team, is an integral part of health care and does not encroach on the area of other health agencies. In fact, the opposite is true in that it is indispensable for the global health care of patients, being a practice already adopted in several countries. In this context, Storpirtis et al. (2008) note that USP's University Hospital develops activities on education, research and assistance, encouraging multidisciplinary health work.

\section{OBJECTIVE}

The aim of this work was to assess the impact of an educational program on the compliance of hypertensive patients with medication and non-medication treatment at USP University Hospital (HU-USP). 


\section{METHODS}

\section{Patient selection and formation of groups}

HU-USP outpatients of both sexes were recruited in the period spanning from March to December, 2001. Inclusion criteria were no age limit or restriction on race, and absence of other concomitant pathology, except obesity, diabetes and dyslipidemia. Recruitment was performed in the order that patients were discharged from the medical care service, and carried out by means of interviews. Interviews included an introduction by the interviewer, presentation of the goal of the work and an explanation on the importance of the study to be carried out. To set up the EG, patients were invited to take part in the educational program, namely, lectures and provision of individual pharmaceutical advice. Individuals who agreed to take part were assigned to the EG $(n=41)$ in which the educational program was applied. Members of the control group $(n=34)$ were invited to take part in the study, signed the written informed consent form, but were not invited to take part in the lecture or offered individual advice. Randomizing criterion was not utilized in forming the EG and CG.

Patients from the experimental and control groups answered a questionnaire, in their first contact with the pharmacist in charge of the program, which focused on general knowledge of AH. The same questionnaire was completed again 270 days after the initial contact to compare the results. From this first contact, patients were given advice on how to collect 24 hour urine samples, and also on taking arterial pressure, measuring cardiac rate $(\mathrm{CF})$, waist and hip circumference and height. Patients of the experimental group were asked to return to the clinic to attend the first lecture of the educational program.

All participants of the study signed the written informed consent form approved by the Research Ethics Committee of USP University Hospital, under number 216/01.

\section{Educational program applied to the experimental group}

The experimental group received guidance by means of lectures and also on a one-to-one basis. The lectures were presented to the participants in clear and easy language, with illustrative didactic material (slides and educational brochures) and were divided into three parts:

- information on the disease, emphasizing its risks when not controlled, and the potential benefit of the non-medication treatment.

- notions on antihypertensive medication, duration of effect, interaction with other medication and food, most frequent adverse reactions, and emphasis on the potential benefit expected from medication and non-medication treatment, according to Urquhart (2000).

discussion on the contents of the questionnaire used in the interview.

The three lectures were given to groups of about 10 patients, at intervals of approximately 2 to 4 months, depending on their ability to attend. During these returns for the lectures, measures of arterial pressure, cardiac rate, weight, waist and hip circumference were taken and individual advice given when necessary. The control group did not take part in the lectures or receive individual advice.

\section{Assessment of treatment compliance}

Assessment of the results was carried out in the two experimental and control groups by means of the following procedures:

Arterial pressure measurement: all patients had their arterial pressure (AP) measured in a seated position, with mercury or aneroid sphygmomanometer graded by INMETRO, according to the Joint National Committee's recommendations (1997).

Height, waist and hip circumference weight and measures: both the weighing with patients in shoes, coats and empty pockets, and measures of height were performed on a set of hospital scales, whereas a new universal measuring tape was used to take waist and hip circumference measures.

Total, fraction and tryacylglicerol serum cholesterol concentrations: the total and fraction serum concentrations (High-Density lipoproteins and Low-density lipoproteins) as well as tryacylglicerol (TG), were carried out within the Clinical Laboratory Service of the HU-USP by the methods:

- Total cholesterol: enzymatic Trinder method with Ames kit;

- HDL: direct, without precipitation in immunoassay with Diasys kit;

- $\quad$ LDL: through calculations;

- $\quad$ TG: GPO-PAP Trinder with Merck kit.

The results of these determinations were obtained from HU-USP patients' medical records.

Sodium and potassium levels excreted in 24-hour urine: in order to better assess the amount of sodium and potassium taken by the patient at the end of, and during the week, samples of 24-hour urine were requested and collected on three different days: Sunday, Monday and Tuesday. Concentration of sodium and potassium from the 24-hour 
urine were measured by flame-emission spectrophometry. The sodium and potassium urine concentration (mmol/liter) was multiplied by the volume of 24-hour diuresis (1iters) to calculate the daily excretion of these electrolytes (mmol/24 hours). The arithmetic mean of the three daily amounts was calculated for purposes of statistical analysis.

Questionnaire: The previously validated questionnaire was applied to patients in the first interview and again after the educational process. The scale comprised two parts with guided questions: the first part had 15 yes/no-type questions on general, basic aspects on $\mathrm{AH}$, and the second part had 7 questions which assessed whether the patient considered themselves compliant or not with the treatment, where answers offered three options (yes, no and I am not in treatment).

\section{Periodicity of data collection}

Variable follow-up: Arterial Pressure (AP), CF, Weight, Height and Body Mass Index (BMI) were recorded at 120,180 and 270-day intervals after the first contact with patients. Regarding waist/hip ratio, serum dosages of total and fraction cholesterol, triacylglycerol, sodium and potassium concentrations excreted in 24-hour urine and percentage of correct answers on the questionnaires, data from the period of the first interview and after 270 days were collected.

\section{Patient grouping}

Although the experimental and control group patients were all hypertensive, they were divided into three groups for the purpose of analysis:

- $\quad$ Experimental group (EGT) and total control group (CGT) comprised all patients of the group.

- $\quad$ Experimental group (EGH) and intense control group (CGH) comprised patients with non-controlled arterial pressure.

- $\quad$ Experimental group (EGN) and normotensive control group (CGN) comprised patients with controlled arterial pressure.

The separation of patients with controlled arterial pressure from those with no arterial pressure was important to best assess the results.

\section{Statistical treatment}

The results were expressed as means \pm standard deviation $(\mathrm{M} \pm \mathrm{SD})$. The significance level considered was $5 \%$. The following tests were utilized to analyze the variables of the present study: Paired Student's t-test; Non- paired Student's t-test; Mann-Whitney and Kruskal-Wallis nonparametric tests; Spearman's coefficient correlation and logistic regression.

\section{RESULTS}

The experimental and control group population were studied to determine their composition, in terms of the following qualitative variables: sex, race, age group, marital status, education, professional activity, salary range, smoking, alcoholism, physical activity (Table I). The following quantitative variables were also analyzed: systolic arterial pressure (SAP), diastolic arterial pressure (DAP), cardiac rate (CR), weight, body mass index (BMI), waist/hip ratio $(\mathrm{W} / \mathrm{H})$, total cholesterol, high density lipoprotein (HDL), low density lipoprotein (LDL), triacylglycerols (TG), sodium excretion in 24-hour urine (UnaV) and potassium in 24-hour urine (UKV), 24-hour sodium/potassium excretion ratio (UNaV/UKV) and score on questionnaire (Table II). Compliance of the study patients with antihypertensive treatment was also evidenced by their attendance to lectures and/or to deliver their urine samples for potassium measures, on the agreed dates, besides the answers to questionnaires. Out of the 41 patients in the experimental group, $71 \%$ attended the lectures and $62 \%$ attended the 2 nd phase of the 24 -hour urine exam, while $72 \%$ of the control group completed the 2 nd phase of the 24-hour urine exam.

Obesity was detected (BMI over 30 ) in $44 \%$ of patients in the experimental group (EG) and $35 \%$ in the control group (CG); $15 \%$ of diabetic patients were found in the EG and $12 \%$ in the $\mathrm{CG}$, while $17 \%$ of patients had high cholesterol (levels above $240 \mathrm{mg} / \mathrm{dL}$ (Blumenthal, 2000), in the EG and 44\% in the CG.

Out of the 41 patients comprising the experimental group, $51 \%$ showed at study baseline, an AP higher or close to $140 \mathrm{X} 90 \mathrm{mmHg}$, whereas in the control group the percentage found was $71 \%$. In the EG and the CG, $48 \%$ and $21 \%$ of patients, respectively, who had an AP higher or close to 140 X $90 \mathrm{mmHg}$ at baseline, were successful in normalizing AP. However, approximately $10 \%$ of the patients of both groups considered themselves noncompliant, according to their answers to the questionnaires. $\mathrm{AP}$ in EGN and CGN remained under control.

Approximately $12 \%$ of patients in both the EG and the CG groups controlled AP without medication through changes in lifestyle. Out of those who took antihypertensive medication, approximately $40 \%$ had monotherapy and around $30 \%$ had treatment with 2 medications, a diuretic medication associated with a beta-blocker, inhibitor of ACE or calcium channel antagonist. The association of 
TABLE I - Profile of experimental and control group total populations

\begin{tabular}{|c|c|c|c|c|c|}
\hline \multirow[t]{2}{*}{ Qualitative variables } & \multirow[t]{2}{*}{ Grouping } & \multicolumn{2}{|c|}{$\begin{array}{l}\text { Experimental Group } \\
n=41\end{array}$} & \multicolumn{2}{|c|}{$\begin{array}{c}\text { Control Group } \\
\mathrm{n}=34\end{array}$} \\
\hline & & $\%$ & $\mathrm{~N}$ & $\%$ & $\mathrm{~N}$ \\
\hline \multirow[t]{2}{*}{$\overline{\operatorname{Sex}}$} & Female & 70.7 & 29 & 52.9 & 18 \\
\hline & Male & 29.3 & 12 & 47.1 & 16 \\
\hline \multirow[t]{2}{*}{ Race } & Non Caucasian & 39.0 & 16 & 38.2 & 13 \\
\hline & Caucasian & 61.0 & 25 & 61.8 & 21 \\
\hline \multirow[t]{3}{*}{ Age Group } & 31 to 50 years & 36.6 & 15 & 35.3 & 12 \\
\hline & 51 to 70 years & 46.3 & 19 & 52.9 & 18 \\
\hline & Above 70 years & 17.1 & 07 & 11.8 & 04 \\
\hline \multirow[t]{2}{*}{ Marital Status } & Married & 82.9 & 34 & 79.4 & 27 \\
\hline & Single & 17.1 & 07 & 20.6 & 07 \\
\hline \multirow[t]{2}{*}{ Education } & Up to full 1 st year & 68.3 & 28 & 70.6 & 24 \\
\hline & From secondary school unfinished & 31.7 & 13 & 29.4 & 10 \\
\hline \multirow[t]{2}{*}{ Professional activity } & Did not work & 41.5 & 17 & 32.4 & 11 \\
\hline & Worked & 58.5 & 24 & 67.6 & 23 \\
\hline Salary rate & $1-5$ & 39.0 & 16 & 44.1 & 15 \\
\hline \multirow[t]{2}{*}{ (minimum wages) } & $5-10$ & 29.3 & 12 & 35.3 & 12 \\
\hline & $>10$ & 31.7 & 13 & 20.6 & 07 \\
\hline \multirow[t]{2}{*}{ Smoking } & Smoking & 17.1 & 07 & 23.5 & 08 \\
\hline & Non smoking & 82.9 & 34 & 76.5 & 26 \\
\hline \multirow[t]{2}{*}{ Alcoholism } & 1 (Yes) & 12.2 & 05 & 17.6 & 06 \\
\hline & $2(\mathrm{No})$ & 87.8 & 36 & 82.4 & 28 \\
\hline \multirow[t]{2}{*}{ Physical activity } & 1 (Yes) & 43.9 & 18 & 44.1 & 15 \\
\hline & $2(\mathrm{No})$ & 56.1 & 23 & 55.9 & 19 \\
\hline \multirow[t]{3}{*}{ Heredity } & Yes & 82.9 & 34 & 79.4 & 27 \\
\hline & No & 9.8 & 04 & 17.7 & 06 \\
\hline & Does not know & 7.3 & 03 & 2.9 & 01 \\
\hline
\end{tabular}

three, four or up to five of the medications outlined were prescribed if necessary for most patients. No correlation between the use of a given kind or association of medications and its dosage, and AP control was found.

Analysis of the percentage variation of the studied quantitative variables in the period of 270 days in the experimental and control hypertension, normotension and total groups, revealed significant differences for five variables. The arterial (systolic and diastolic) pressures decreased in the hypertensive experimental group; the triacylglycerol amounts decreased in the total experimental group; the waist/hip ratio fell in the hypertensive experimental group, whereas the potassium urine excretion in 24-hour volume increased in the total experimental group, and the percentage of correct responses on the questionnaires also increased in the normotensive experimental group, all in comparison to the respective control groups. No significant differences were seen for the other variables studied.

\section{Systolic and diastolic arterial pressure}

A significant percentage fall in arterial pressure was noted (SAP and DAP) in the EGH. SAP showed a $-8.8 \pm 10.5$ variation in the EGH vs. $1.1 \pm 5.3$ in the $\mathrm{CGH}$ $(\mathrm{p}=0.0005)$ (Figure 1), and DAP showed a $-9.4 \pm 8.6$ variation in the $\mathrm{EGH}$ vs. $-2.7 \pm 5.7$ in the $\mathrm{CGH}(\mathrm{p}=0.01)$ (Figure 2).

\section{Waist/hip ratio}

EGH vs. CGH showed a significant difference for these variables, which decreased in the experimental groups 
and increased in the control groups. EGH had a percentage change of $-1.3 \pm 2.7 \times 3.5 \pm 4.7$ of CGH ( $p=0.001)$ (Figure 3 ).

\section{Triacylglycerols (triglycerides)}

Triacylglycerol amounts decreased in the EGT and increased in the CGT. There was a significant percentage difference for this variable, with amounts of $-1.9 \pm 31.7$ and $48.7 \pm 71.3$ for EGT and CGT, respectively $(\mathrm{p}<0.05)$ (Figure 4).

\section{Urine potassium excretion in 24-hour volume}

The EGT showed a greater increase in potassium excretion compared to the CGT. There was a percentage difference for this variable between the EGT and CGT,

TABLE II - Baseline values for Quantitative variables in the total experimental and control groups

\begin{tabular}{lcccc}
\hline Qualitative variables & \multicolumn{2}{c}{ Control Group TOTAL } & \multicolumn{2}{c}{ Control Group TOTAL } \\
\cline { 2 - 5 } & Mean \pm SD & $\mathrm{N}$ & Mean \pm SD & $\mathrm{N}$ \\
\hline Systolic arterial pressure (mmHg) & $144 \pm 19.6$ & 41 & $147 \pm 16.1$ & 34 \\
Diastolic arterial pressure (mmHg) & $89 \pm 11.7$ & 41 & $92 \pm 13.1$ & 34 \\
Cardiac rate (bpm) & $70 \pm 8.6$ & 41 & $72 \pm 11.5$ & 34 \\
Weight (kg) & $72.3 \pm 14.4$ & 40 & $72.9 \pm 14.1$ & 32 \\
Body mass index (kg/m ${ }^{2}$ ) & $29.2 \pm 5.1$ & 40 & $28.5 \pm 4.2$ & 32 \\
Waist/hip ratio & $0.87 \pm 0.07^{*}$ & 29 & $0.92 \pm 0.09$ & 24 \\
Total cholesterol (mg/dL) & $205.6 \pm 28.4$ & 19 & $197.0 \pm 44.55$ & 14 \\
High density lipoprotein (mg/dL) & $49.5 \pm 12.4$ & 19 & $48.6 \pm 12.1$ & 14 \\
Low density lipoprotein (mg/dL) & $130.2 \pm 21.8$ & 19 & $125.5 \pm 27.5$ & 13 \\
Triacylglycerols (mg/dL) & $130.3 \pm 39.8$ & 18 & $124.3 \pm 52.7$ & 15 \\
Sodium urine excretion in 24-hour volume (mEq/24 hours) & $144.1 \pm 45.8 * * *$ & 24 & $190.3 \pm 55.8$ & 24 \\
Urine potassium excretion in 24-hour volume (mEq/24 hours) & $47.9 \pm 16.0 * *$ & 24 & $60.7 \pm 21.5$ & 24 \\
24-hour sodium and urine potassium excretion ratio & $3.1 \pm 1.0$ & 24 & $3.4 \pm 1.2$ & 24 \\
Questionnaire score (percentage correct) & $87.6 \pm 9.0$ & 29 & $85.3 \pm 6.8$ & 24 \\
\hline Amy
\end{tabular}

Amounts expressed as mean \pm standard deviation. $* \mathrm{P}<0.05 \mathrm{X}$ control, $* * \mathrm{P}=0.02,{ }^{*} * \mathrm{P}<0.01 \mathrm{X}$ control

\section{Percentage change}

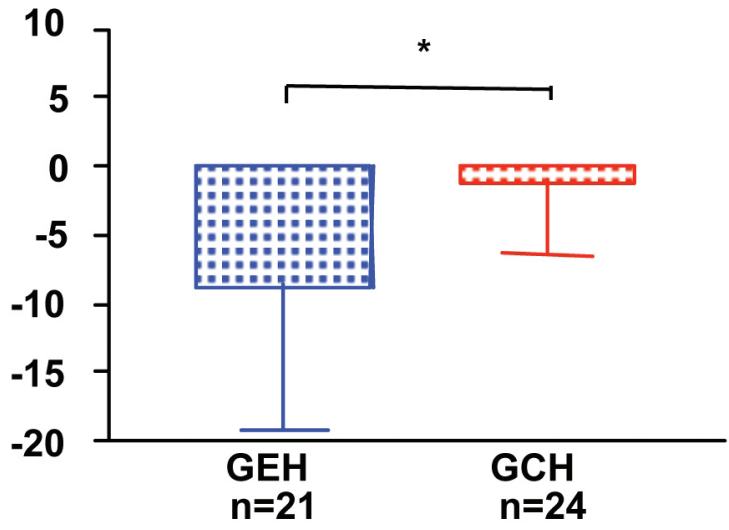

FIGURE 1 - Percentage change \pm SD in systolic arterial pressure between time 0 and the arithmetic mean of measures after 120 , 180 and 270 days in the hypertensive experimental group (EGH) and hypertensive control group $(\mathrm{CGH}) .{ }^{*} \mathrm{p}=0.0005$. EGH $n=21$ (21 patients in EG with SAP above $140 \mathrm{mmHg}$ on the 1 st AP measurement); $\mathrm{CGH} n=24$ ( 24 patients in $\mathrm{CG}$ with SAP above $140 \mathrm{mmHg}$ on the 1 st AP measure).

\section{Percentage change}

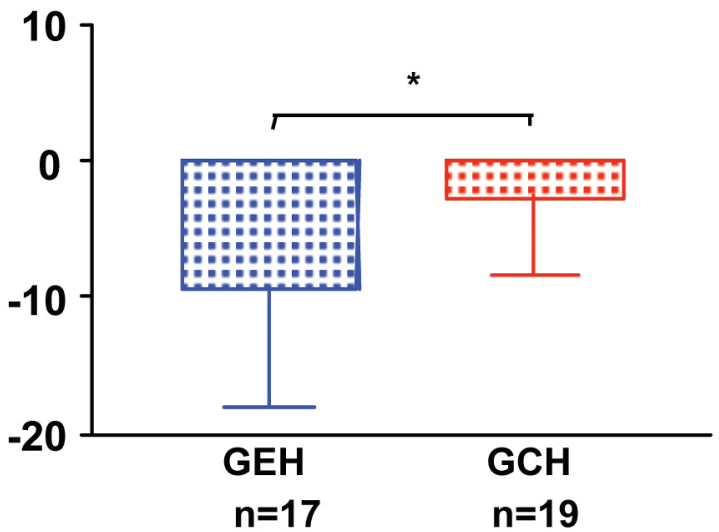

FIGURE 2 - Percentage change \pm SD of diastolic arterial pressure between time 0 and the arithmetic mean of the measures after 120,180 and 270 days in the hypertensive experimental group $(\mathrm{EGH})$ and hypertensive control group $(\mathrm{CGH}) .{ }^{*} \mathrm{p}=0.01 \mathrm{EGH}$ $\mathrm{n}=17$ (17 patients in EG with SAP above $90 \mathrm{mmHg}$ on the $1 \mathrm{st}$ AP measure); $\mathrm{CGH} n=19$ (19 patients of $\mathrm{CG}$ with DAP above $90 \mathrm{mmHg}$ on the 1 st AP measure). 


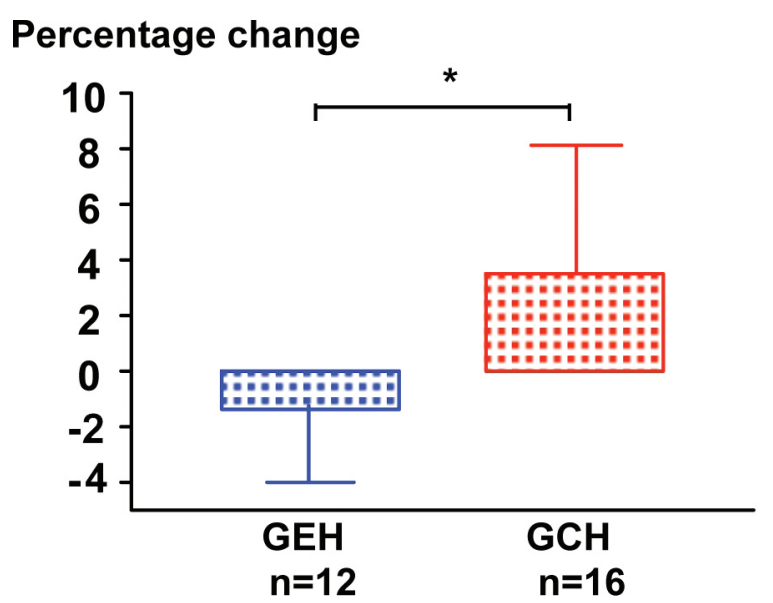

FIGURE 3 - Percentage change $\pm \mathrm{SD}$ of the waist/hip ratio between time 0 and 270 (days), in the hypertensive experimental group (EGH) and hypertensive control group (CGH). ${ }^{*} \mathrm{p}=0.001$. $\mathrm{EGH} n=12$ (12 patients of the hypertensive experimental group provided measures needed for comparisons). CGH $n=16$ (16 patients of the hypertensive control group provided measures needed for comparisons).

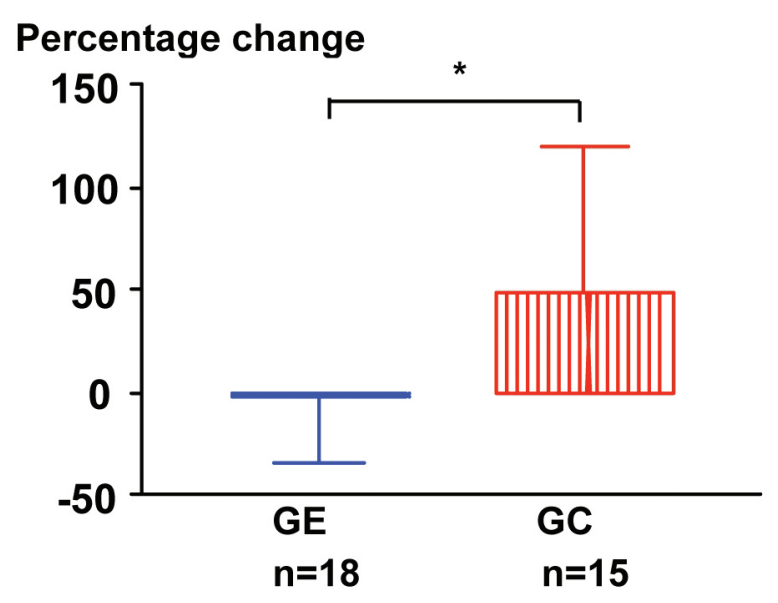

FIGURE 4 - Percentage change \pm SD of tryacylglicerol between time 0 and 270 (days) in the experimental group (EGT) and total control group (CGT). ${ }^{*} \mathrm{p}<0.05$. EGT $n=18$ (18 patients of the total experimental group attended the required exam sessions). CGT $n=15$ (15 patients of the total control group attended the required exam sessions).

with amounts of $26.1 \pm 37.6$ and $1.2 \pm 29$, respectively $(\mathrm{p}<0.05)$ (Figure 5).

\section{Percentage of correct responses on questionnaires}

The experimental group of normotensive patients performed better in terms of the percentage of right answers than did the respective control group. EGN vs.

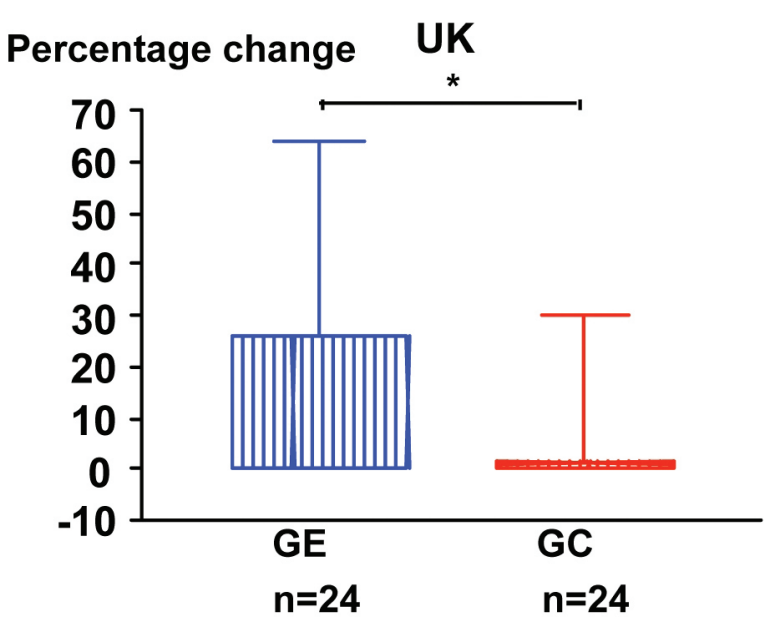

FIGURE 5 - Percentage change \pm SD in 24-hour urine potassium excretion (UKV) between time 0 and 270 (days) in the total experimental group (EGT) and total control group (CGT). ${ }^{*} \mathrm{p}<0.05$. EGT $n=24$ (24 patients of the total experimental group attended the required exam sessions). CGT $n=24$ (24 patients of the total control group attended the attended the required exam sessions).

\section{Percentage change}

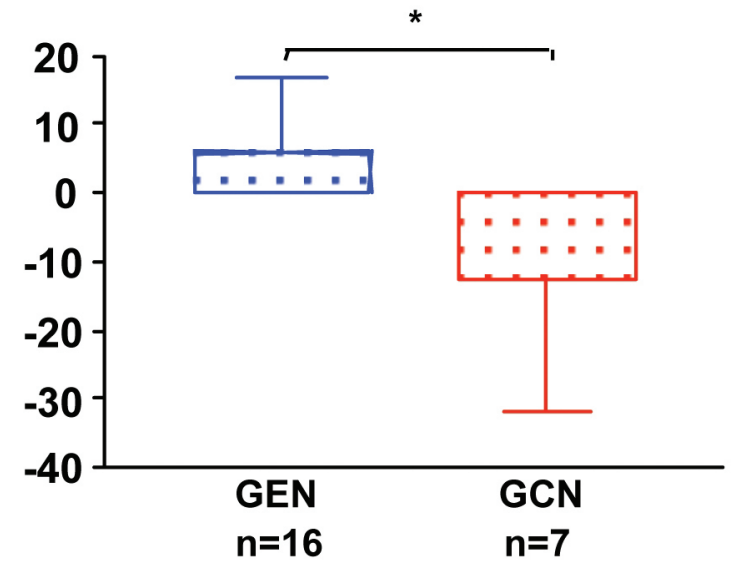

FIGURE 6 - Percentage change \pm SD in correct responses on questionnaires between time 0 and 270 (days) in the normotensive experimental group (EGN) and normotensive control group (CGN). ${ }^{*} \mathrm{p}<0.006$. EGN $n=16$ (16 patients of the normotensive experimental group attended the sessions to answer the questionnaire). $\mathrm{CGN} n=07$ ( 7 patients of the normotensive control group attended the sessions to answer the questionnaire).

CGN showed a percentage difference of $5.9 \pm 10.8 \mathrm{vs}$. $-12.4 \pm 19.3(p=0.006)$, i.e., in the control group there was a decrease in the number of correct answers (Figure 6).

\section{DISCUSSION}

Of the variables studied and outlined, the following 
showed significant results: AP, triglycerides, waist/hip reaction, urine potassium excretion in 24-hour volume and percentage of correct answers on questionnaires.

In the hypertensive experimental group, there was a significant percentage decrease in systolic and diastolic pressures (Figures 1 and 2), with results comparable to those found by Mcgowan (2008); the same group showed a significant decrease in waist/hip ratio (Figure 3), which suggests greater compliance with the treatment by the hypertensive patients of the experimental group.

The reduction in the amounts of triacylglycerol in the EGT alone (Figure 4), did not indicate a change in food habits with fat restrictions, since the other serum lipids did not suffer a significant alteration in the studied population. However, it is possible to deduce that there was a change in the habits regarding physical activities, based on the decrease in waist/hip ratio and triacylglycerols.

With regard to the significant increase in urine excretion of potassium in the EG, it is possible that these patients complied with the advice on food habit changes, increasing their intake of potassium-rich fruit and vegetables; notably the patients from both the EG and CG used the following types of medication to control $\mathrm{AH}$ : adrenergic beta-blockers, antagonists of calcium channel, angiotensin converting enzyme (ACE) inhibitors, angiotensin II AT1 receptor antagonists, peripheral vasodilation action, besides thiazidic diuretics that promote the increase of urine potassium excretion. However, $59 \%$ of the patients in the EG who had increased potassium urine secretion were not in use of thiazidic diuretics; likewise, in the CG, 55\% of the patients who showed an increase in urine potassium excretion were not using this type of medication. It is also noteworthy that, among the population of EG patients who did not show an increase in urine potassium excretion, $56 \%$ used IECA or ARA II or aldosterone antagonist diuretics (medications that decrease urine potassium excretion) compare with $39 \%$ of the CG population that did not show an increase in urine potassium excretion, thus reinforcing the possibility of changes in food habits in the EG (Figure 5).

The increase in correct answers on EG questionnaires suggests assimilation of the information given during the teaching process. EG normotensive patients showed more satisfactory results in answers on the questionnaires than did the CG patients (Figure 6). They were possibly responsible for the increase of correct answers observed in total experimental group questionnaires, since the hypertensive patients of the experimental group showed no increase in the percentage of correct answers in the studied period.

Several studies in the literature such as those by Dobs (1994) and Roca-Cusachs (1991), show that edu- cation is a process and, as such, cannot change patient's attitudes overnight, attitudes which have often been ingrained for decades. However, the evolution of the variables studied in the patients of the present study suggests that the knowledge acquired in the educational process increased patients' awareness, motivating them to continue complying with the advice received. This change in behavior was also observed by Green (2008), who showed that Pharmaceutical Care, applied for 12 months, although given over the Internet, resulted in better control of $\mathrm{AH}$ (in $56 \%$ of patients) in comparison to patients who did not receive guidance ( 31 to $36 \%$ ). The present study found similar results in terms of AP control, which was achieved in $48 \%$ of the experimental patients versus $21 \%$ of the control patients). This study investigated the effectiveness of education as a preventive measure in the fight against the devastating effects of nontreated or poorly-treated $\mathrm{AH}$, indicating that it is possible to improve adherence to treatment and, as a result achieve controlled clinical and laboratorial results by means of educational practices (Green, 2008; McGowan, 2008; Collins, 1999).

\section{CONCLUSION}

The educational process applied under the conditions of the present study, improves clients' clinical response to antihypertensive treatment, and should be included in the therapeutic strategies of health care services dealing with hypertensive patients.

\section{ACKNOWLEDGMENTS}

The authors wish to thank the Pharmacy Department of the Faculty of Pharmaceutical Sciences of the USP, the Outpatient Clinic for Metabolic Diseases and Division of Pharmacy and Clinical Laboratory of the HU-USP, and the Sector of Experimental Hypertension of the Laboratory of Renal Physiopathology of the Department of Clinical Medicine of the Faculty of Medicine of the USP, for their support in conducting the present study.

We would also like to extend our thanks to the patients for their interest, good will and rewarding acquaintanceship.

\section{REFERENCES}

BASILE, J. N. Combination agents as a means of improving adherence and other aspects of the sixth joint national committee report. South. Med. J., v.93, n.5, p.534-536, 2000 . 
BLUMENTHAL, J. A.; SHERWOOD, A.; GULLETTE, E. C. D.; BABYAK, M.; WAUGH, R.; GEORGIADES, A.; CRAIGHEAD, L. W.; TWEEDY, D.; FEINGLOS, M.; APPELBAUM, M.; HAYANO, J.; HINDERLITER, A. Exercise and weight loss reduce blood pressure in men and women with mild hypertension. Arch. Intern. Med., v.160, n.10, p.1947-1958, 2000.

BONAL, J. Experiências em Atenção Farmacêutica. In: STORPIRTIS, S.; MORI, A. L. P. M.; YOCHIY, A.; RIBEIRO, E.; PORTA, V. (Eds.). Ciências Farmacêuticas. Farmácia Clínica e Atenção Farmacêutica. São Paulo: Guanabara Koogan, 2008. cap.44, p.451-460.

BROUKER, M. E.; GALLANGHER, K.; LARRAT, E. P.; DUFRESNE, R. L. Patient compliance and blood pressure control on a nuclear-powered aircraft carrier: impact of a pharmacy officer. Mil. Med., v.165, n.2, p.106-110, 2000.

BURNIER, M. Long-term compliance with antihypertensive therapy: another facet of chronotherapeutics in hypertension. Blood Press. Monit., v.5, suppl 1, p.S31-S34, 2000.

COLLINS, L., IVEY, A. M. The relationship of pacient education and hypertension treatment compliance. J. Am. Acad. Nurs. Pract., v.11, n.8, p.331-334, 1999.

DOBS, A. S.; MASTERS, R. B.; RAJARAM, L.; STILLMAN, F.A.; WILDOER, L.B.; MARGOLIS, S.; BECKER, D. M. A comparison of education methods and their impact on behavioral change in patients with hyperlipidemia. Patient Educ. Couns., v.24, n.2, p.157-164, 1994.

GREEN, B. B. Home monitoring plus web-based pharmacist care helps lower blood pressure. JAMA, v.299, n.24, p.28542867,2008

HEISLER, M.; HOGAN, M. M.; HOFER,T. P.; SCHMITTDIEL, J. A.; PLADEVALL, M.; KERR, E. A. When more is not better. Treatment intensification among hypertensive patients with poor medication adherence. Circulation., v.117, n.22, p.2884-2892, 2008.

HERMANSEN, K. Diet, blood pressure and hypertension. $B r$. J. Nutr., v.83, suppl.1, p.S113-S119, 2000.
IVAMA, A. M.; JARAMILLO, N. M. A educação farmacêutica no contexto de mudança do modelo de atenção à saúde e reorientação da prática farmacêutica. In: STORPIRTIS, S.; MORI, A. L. P. M.; YOCHIY, A.; RIBEIRO, E.; PORTA, V. (Eds.). Ciências Farmacêuticas. Farmácia Clínica e Atenção Farmacêutica. São Paulo: Guanabara Koogan, 2008. cap.33, p.317-331.

JOHNSON, M. J.; WILLIAMS, M.; MARSHALL, E. S. Adherent and nonadherent medication-taking in elderly hypertensive patients. Clin. Nurs. Res., v.8, n.4, p.318-335, 1999.

JOINT NATIONAL COMMITTEE ON PREVENTION, DETECTION, EVALUATION AND TREATMENT OF HIGH BLOOD PRESSURE, 7, NATIONAL HIGH BLOOD PRESSURE EDUCATION PROGRAM COORDINATING COMMITTEE. The seventh report of the Joint National Committee on Detection, Evaluation, and Treatment of High Blood Pressure (JNC VII). U.S. DEPARTMENT OF HEALTH AND HUMAN SERVICES. National High Blood Pressure Education Program. NIH Publication n.04-5230, p.1-104, 2004. Available at: <http:// www.nhlbi.nih.gov/guidelines/hypertension/jnc7full.pdf $>$. Access on: may 16th 2008.

JOINT NATIONAL COMMITTEE ON PREVENTION, DETECTION, EVALUATION AND TREATMENT OF HIGH BLOOD PRESSURE, 6, NATIONAL HIGH BLOOD PRESSURE EDUCATION PROGRAM COORDINATING COMMITTEE. The sixth report of the Joint National Committee on Detection, Evaluation, and Treatment of High Blood Pressure (JNC VI). Arch. Intern. Med., v.157, n.21, p.2413-2446, 1997.

KORHONEN, M. H.; LITMANEN, H.; RAURAMAA, R.; VAISANEN, S. B.; NISKANEN, L.; UUSITUPA, M. I. J. Adherence to the salt restriction diet among peole with mildly elevated blood pressure. Eur. J. Clin. Nutr., v.53, n.11, p.880-885, 1999.

McGOWAN, N.; COCKBURN, A.; STRACHAN, M. W. J.; PADFIELD, P. L.; MCKNIGHT, J. a. Initial and sustained cardiovascular risk reduction in a pharmacist-led diabetes cardiovascular risk clinic. Br. J. Diabetes Vasc. Dis., v.8, n.1, p.34-38, 2008.

MARGETTS, B. M.; LITTLE, P.; WARM, D. Interaction between physical activity and diet: implications for blood pressure management in primary care. Public Health Nutr., v.2, n.3A, p.377-382, 1999. 
NEUTEL, J. M. The role of combination therapy in achieving blood pressure control. Am. J. Manag. Care, v.5, suppl.7, p.463-468, 1999.

NICHOLS-ENGLISH, G.; POIRIER, S. Optimizing adherence to pharmaceutical care plans. J. Am. Pharm. Assoc., v.40, n.4, p.475-485, 2000.

ORGANIZAÇÃO PAN-AMERICANA DA SAÚDE. Consenso Brasileiro de Atenção Farmacêutica: proposta. Brasília, 2002. 23p.

QUINTA Diretrizes Brasileiras de Hipertensão Arterial. Rev. Bras. Hipertens., v.13, n.4, p.260-312, 2006.

ROCA-CUSACHS, A.; SORT, D.; ALTIMIRA, J.; BONET, R.; GUILERA E.; MONMANY, J.; NOLLA, J. The impact of a patient education programme in the control of hypertension. J. Hum. Hypertens., v.5, n.5, p.437-441, 1991.

STORPIRTIS, S.; SUGAWARA, E.; RICCI, M. C. S.; PORTA, V.; RIBEIRO, E.; MORI, A. L. P. M. Ensino e Prática da Farmácia Clínica e Atenção Farmacêutica na Faculdade de Ciências Farmacêuticas e no Hospital Universitário da Universidade de São Paulo. In: STORPIRTIS, S.; MORI, A. L. P. M.; YOCHIY, A.; RIBEIRO, E.; PORTA, V. (Eds.). Ciências Farmacêutica: Farmácia Clínica e Atenção Farmacêutica. São Paulo: Guanabara Koogan, 2008. cap.37, p.367-374.
TERCEIRO Consenso Brasileiro de hipertensão arterial. Hipertensão arterial: tratamento medicamentoso. Rev. Bras. Clin. Ter., v.24, n.5, p.253-261, 1998.

URQUHART, J. Erratic patient compliance with prescribed drug regimens: target for drug delivery systems. Clin. Pharmacol. Ther, v.67, n.4, p.331-334, 2000.

WAEBER, B., BURNIER, M., BRUNNER, H. R. How to improve adherence with prescribed treatment in hypertensive patients? Cardiovasc. Pharmacol., v.35, suppl.3, p.S23-S26, 2000.

WEIER, M. R.; MAIBACH, E. W.; BAKRIS, G. L.; BLACK, H. R.; CHAWLA, P.; MESSERLI, F. H.; NEUTEL, J. M.; WEBER, M. A. Implications of a health lifestyle and medication analysis for improving hypertension control. Arch. Intern. Med., v.160, n.28, p.481-490, 2000.

Received for publication on $29^{\text {th }}$ September 2008 Accepted for publication on $15^{\text {th }}$ July 2009 